\title{
Komparasi Pembelajaran Statistika Melalui Pendekatan CTL dan Problem-Posing Ditinjau dari Prestasi Belajar dan Minat Belajar Matematika
}

\author{
Nevi Narendrati \\ Universitas Mercubuana Yogyakarta. Jalan Wates Km. 10 Yogyakarta 55753, Indonesia \\ Email: nevi.naren@gmail.com \\ Received: 25 January 2017; Revised:25 April 2017; Accepted: 5 May 2017
}

\begin{abstract}
Abstrak
Penelitian ini bertujuan untuk mendeskripsikan keefektifan pembelajaran statistika melalui pendekatan CTL dan pendekatan problem posing ditinjau dari prestasi belajar dan minat belajar matematika, dan menyelidiki manakah yang lebih efektif antara pembelajaran statistika melalui pendekatan CTL dan pendekatan problem posing ditinjau dari prestasi belajar dan minat belajar matematika siswa SMK. Penelitian ini adalah penelitian eksperimen semu, dengan rancangan pretest-posttest non-equivalent group design. Populasi penelitian mencakup seluruh siswa kelas XI SMK Negeri 5 Yogyakarta. Dari populasi yang ada diambil secara acak dua kelas sebagai sampel penelitian. Untuk menguji keefektifan pendekatan CTL dan problem posing digunakan analisis one sample t-test pada aspek prestasi dan uji proporsi pada aspek minat. Selanjutnya untuk membandingkan keefektifan pembelajaran matematika melalui pendekatan CTL dan problem posing, data dianalisis secara multivariat menggunakan uji $T^{2}$ Hotelling. Jika terdapat perbedaan keefektifan, maka dilakukan uji lanjut t-univariat untuk menentukan variabel tertentu yang berkontribusi terhadap perbedaan secara keseluruhan. Hasil penelitian menunjukkan bahwa: (1) pembelajaran statistika melalui pendekatan CTL efektif ditinjau dari prestasi belajar matematika; (2) pembelajaran statistika melalui pendekatan problem posing efektif ditinjau dari prestasi belajar dan minat belajar matematika siswa SMK; (3) tidak terdapat perbedaan keefektifan antara pembelajaran statistika melalui pendekatan CTL dan pendekatan problem posing ditinjau dari prestasi belajar dan minat belajar matematika siswa SMK.
\end{abstract}

Kata Kunci: pendekatan CTL, pendekatan problem posing, prestasi belajar, minat belajar matematika

\section{A Comparison of Statistics Learning Through CTL and Problem-Posing Approach in Terms of Learning Achievement and Interest in Learning Mathematics}

\begin{abstract}
This research aims to describe the effectiveness of statistics learning through the CTL approach and problem posing approach in terms of learning achievement and interest in learning mathematics and to investigate which approach is more effective in learning mathematics for Vocational School students. This research is a quasi-experimental research using the pretest-posttest non-equivalent group design. The research population comprised all year XI students of SMK Negeri 5 Yogyakarta. From the population, two classes were randomly selected as the research sample. To test the effectiveness of statistics learning through the CTL and problem-posing approach, one sample t-test was used in the aspect of learning achievement and a proportion test on the aspect of interest in learning. The data were analyzed using the $T^{2}$ Hotelling's test to compare the effectiveness of the CTL approach and problem-posing approach. If differences in effectiveness were found, then further study of t-univariate was done to determine certain variables that contributed to the overall difference. The results show that: (1) statistics learning through the CTL approach is effective in terms of learning achievement; (2) statistics learning through the problemposing approach is effective in terms of learning achievement and interest in learning mathematics; (3) there is no difference between the effectiveness of teaching using the CTL approach and teaching using the problem-posing approach in terms of learning achievement and interest in learning mathematics among Vocational School students.
\end{abstract}

Keywords: CTL approach, problem-posing approach, learning achievement, interest in learning mathematics

How to Cite: Narendrati, N. (2017). Komparasi pembelajaran statistika melalui pendekatan CTL dan problem posing ditinjau dari prestasi belajar dan minat belajar matematika. Jurnal Riset Pendidikan Matematika, 4(1), 6777. doi:http://dx.doi.org/10.21831/jrpm.v4i1.12723 


\section{Jurnal Riset Pendidikan Matematika, 4 (1), 2017 - 68}

Nevi Narendrati

\section{PENDAHULUAN}

Pendidikan memegang peranan besar dalam kemajuan suatu bangsa. Hal ini disebabkan pendidikan adalah sektor yang dapat menciptakan kecerdasan manusia untuk melangsungkan kehidupannya. Undang-undang Nomor 20 Tahun 2003 tentang Sistem Pendidikan Nasional, Pasal 3 menegaskan bahwa pendidikan nasional berfungsi mengembangkan kemampuan dan membentuk watak serta peradaban bangsa yang bermartabat dalam rangka mencerdaskan kehidupan bangsa, bertujuan untuk berkembangnya potensi peserta didik agar menjadi manusia yang beriman dan bertakwa kepada Tuhan Yang Maha Esa, berakhlak mulia, sehat, berilmu, cakap, kreatif, mandiri, dan menjadi warga negara yang demokratis serta bertanggung jawab. Tujuan pendidikan berusaha untuk membangun ketangguhan akhlak dalam lingkup spesifik maupun universal. Maka dari itu untuk mencapai tujuan pendidikan yang diharapkan, khususnya lembaga pendidikan, perlu untuk mengkaji metode proses pendidikan demi terlaksananya tujuan pendidikan itu sendiri (Presiden Republik Indonesia, 2003).

Pembelajaran di sekolah menengah kejuruan memiliki tujuan yang lebih khusus. Pendidikan kejuruan bertujuan untuk meningkatkan kecerdasan, pengetahuan, kepribadian, akhlak mulia, serta keterampilan peserta didik untuk hidup mandiri dan mengikuti pendidikan lebih lanjut sesuai dengan program kejuruannya (Menteri Pendidikan Nasional, 2006). Proses pembelajaran telah diatur dalam Peraturan Menteri Pendidikan dan Kebudayaan Nomor 65 Tahun 2013. Peraturan tersebut menyatakan bahwa proses pembelajaran pada satuan pendidikan diselenggarakan secara interaktif, inspiratif, menyenangkan, menantang, memotivasi peserta didik untuk berpartisipasi aktif, serta memberikan ruang yang cukup bagi prakarsa, kreativitas, dan kemandirian sesuai dengan bakat, minat, dan perkembangan fisik serta psikologis peserta didik. Dengan demikian, sekolah berperan penting dalam mengembangkan potensi anak menjadi manusia yang bermutu. Untuk menciptakan sumber daya yang berkualitas dibutuhkan proses pendidikan yang berkualitas pula. Oleh karena itu, salah satu upaya pemerintah dalam meningkatkan mutu pendidikan sekolah adalah perbaikan proses belajar mengajar yang berkualitas.

Pembelajaran di kelas melibatkan guru dan siswa secara langsung. Kunci pokok pembelajaran ada pada guru (pengajar), tetapi bukan berarti dalam proses pembelajaran hanya guru yang aktif sementara siswanya pasif. Pembelajaran menuntut keaktifan kedua belah pihak yang sama-sama menjadi subjek pembelajaran. Jadi, jika pembelajaran ditandai oleh keaktifan guru sedangkan siswa pasif, maka pada hakikatnya kegiatan itu hanya disebut mengajar. Demikian pula jika pembelajaran dimana siswa yang aktif tanpa melibatkan keaktifan guru untuk mengelolanya secara baik dan terarah, maka hanya disebut belajar. Hal ini menunjukkan bahwa pembelajaran menuntut keaktifan guru dan siswa.

Matematika merupakan suatu mata pelajaran yang memiliki peran penting dalam memaksimakan kemampuan berpikir siswa. Matematika merupakan sarana utama untuk mengembangkan pemikiran logis dan keterampilan kognitif tingkat tinggi anak (Muijs \& Reynolds, 2005, p. 212). Dengan demikian, mata pelajaran matematika perlu diberikan kepada semua peserta didik mulai dari sekolah dasar untuk membekali peserta didik dengan kemampuan berpikir logis, analitis, sistematis, kritis dan kreatif, serta kemampuan bekerja sama.

Kompetensi matematika dibutuhkan agar peserta didik dapat memiliki kemampuan memperoleh, mengelola, dan memanfaatkan informasi untuk bertahan hidup pada keadaan yang selalu berubah, tidak pasti, dan kompetitif. Mempelajari matematika dengan baik akan bermanfaat pada diri seseorang, baik kaitannya dengan kualitas berpikir orang tersebut maupun tentang penerapannya dalam kehidupan seharihari. Matematika sangat dibutuhkan siswa untuk masa depan. Matematika adalah alat yang harus dipelajari seseorang agar dapat bertahan hidup meskipun sering dikatakan sulit, membosankan, bahkan menakutkan (Beall, 2010). Persepsi tersebut disebabkan oleh beberapa faktor, di antaranya yaitu faktor guru dan faktor siswa. Salah satu yang disebabkan oleh faktor guru yaitu mengenai belum tepatnya pendekatan pembelajaran yang diterapkan sehingga terkadang siswa kurang memahami kaitan antara matematika dengan kehidupan sehari-hari. Akibatnya siswa tidak mampu menyelesaikan masalah yang dihadapi dengan pelajaran matematika dan tidak berminat untuk mempelajarinya. Di sinilah guru perlu memperhatikan situasi dan kondisi siswa sebelum menerapkan pendekatan pembelajaran yang akan digunakan. 


\section{Jurnal Riset Pendidikan Matematika, 4 (1), 2017 - 69}

Nevi Narendrati

Dalam praktiknya, pembelajaran matematika biasanya dimulai dengan penjelasan konsep disertai dengan contoh-contoh, dilanjutkan dengan latihan soal. Soal-soal yang disajikan kebanyakan tidak mengaitkan matematika dengan konteks kehidupan siswa sehari-hari. Hal ini membuat pembelajaran matematika jauh dari kehidupan siswa. Dengan kata lain, pelajaran matematika menjadi kurang bermakna. Kekurangnya makna pelajaran matematika bagi siswa berdampak pada prestasi belajar siswa yang akhirnya kurang optimal. Salah satu fakta yang mencerminkan masalah ini adalah data mengenai daya serap matematika siswa dari hasil Ujian Nasional.

Kompetensi matematika yang diujikan pada Ujian Nasional adalah termasuk materi pokok statistika. Data BSNP menunjukkan bahwa daya serap Kota Yogyakarta untuk materi pokok statistika tahun 2012 di tingkat provinsi adalah sebesar 68,91 dan 80,72 di tingkat nasional. Sedangkan tahun 2013 untuk materi pokok yang sama, persentase daya serap siswa mengalami penurunan, yaitu sebesar 44,87 di tingkat provinsi dan 41,18 di tingkat nasional. Hasil Ujian Nasional berupa daya serap siswa khususnya di SMK Negeri 5 Yogyakarta pada materi pokok statistika disajikan pada Tabel 1.

Tabel 1. Daya Serap UN SMK Negeri 5 Yogyakarta

\begin{tabular}{lcc}
\hline \multirow{2}{*}{ Kemampuan yang diuji } & \multicolumn{2}{c}{ Daya Serap } \\
\cline { 2 - 3 } & $\mathbf{2 0 1 2}$ & $\mathbf{2 0 1 3}$ \\
\hline Menghitung ukuran pemusatan data & 54,42 & 24,07 \\
Menghitung ukuran penyebaran data & 67,65 & 44,67 \\
$\begin{array}{l}\text { Menginterpretasi data yang disajikan } \\
\text { dalam bentuk tabel/diagram }\end{array}$ & 91,18 & 25,81 \\
\hline
\end{tabular}

Sumber: BSNP (2012), BSNP (2013)

Berdasarkan Tabel 1, terlihat pada dua tahun terakhir hasil daya serap UN pada materi statistika mengalami penurunan yang cukup signifikan. Hal ini menunjukkan bahwa belum efektifnya pendekatan pembelajaran yang diterapkan apabila ditinjau dari daya serap siswa. Berdasarkan informasi yang diperoleh, siswa mengalami kesulitan pada materi pokok statistika. Misalnya, siswa kesulitan untuk menghitung ukuran pemusatan data. Di samping itu siswa juga mengalami kesulitan untuk menghitung ukuran penyebaran data.

Selain faktor guru, faktor dari dalam diri siswa yang juga memiliki peran besar dalam keberhasilan proses belajar matematika adalah minat belajar. Dengan minat, seseorang akan melakukan sesuatu sesuai apa yang diminatinya.
Sebaliknya, tanpa minat seseorang tidak mungkin melakukan sesuatu. Oleh karena itu, tanpa adanya minat belajar matematika, tujuan pembelajaran tidak akan tercapai. Minat, baik berupa materi teks ataupun kegiatan tugas adalah penting karena mempengaruhi perhatian dan ketekunan dan, dalam jangka panjang, menambah pengetahuan siswa (Alderman, 2008, pp. 240-241).

Minat didefinisikan sebagai sesuatu yang lebih disukai atau dipilih pada kegiatan kerja tertentu (Gable, 1986, p. 8). Minat dapat digambarkan berkaitan dengan target, arah, dan intensitas. Target dari minat adalah aktivitas; arah dapat digambarkan sebagai tertarik atau tidak tertarik; dan intensitas dapat diberi label tinggi atau rendah (Gable, 1986, p. 9). Minat belajar matematika dapat diartikan sebagai keterlibatan diri secara penuh dalam melakukan aktivitas belajar matematika baik di rumah, di sekolah, dan di masyarakat. Siswa yang mempunyai minat belajar matematika berarti mempunyai usaha dan kemauan untuk mempelajari matematika.

Apabila siswa dengan kondisi kurang minat untuk belajar matematika dibiarkan tanpa ada penanganan dari seorang guru, maka yang akan terjadi adalah siswa hanya datang dan duduk untuk menerima materi dari guru, namun siswa tersebut merasa tersiksa dan tidak menikmati saat belajar dengan guru. Pelajaran matematika yang dirasa sulit, ruwet, dan membosankan, akan menjadi pelajaran yang semakin tidak diharapkan oleh siswa. Apabila image ini tetap melekat di hati setiap siswa, maka selamanya matematika akan menjadi pelajaran yang tidak ada maknanya bagi siswa, dan mereka tidak akan pernah berminat untuk bertemu dengan pelajaran matematika. Hal ini akan membuat siswa semakin sulit untuk mencapai hasil kompetensi ketuntasan minimal yang telah ditetapkan. Minat siswa akan meningkat ketika dirinya merasa mampu (Woolfolk, 2007, p. 363).

Berdasarkan wawancara pada prasurvei yang peneliti lakukan dengan guru matematika kelas XI SMK Negeri 5 Yogyakarta, faktanya pembelajaran di kelas masih didominasi oleh pembelajaran konvensional. Guru mengajar secara langsung dan siswa duduk memperhatikan penjelasan guru. Pada beberapa kesempatan guru menerapkan metode diskusi di kelas. Sejauh ini sebagian siswa aktif berpartisipasi dalam pembelajaran, yang berarti minat untuk belajar matematika sudah dimiliki oleh siswa 
tertentu. Akan tetapi menurut pengamatan guru bahwa dari sekitar 30 siswa di kelas, banyaknya siswa yang memiliki minat belajar matematika cukup baik tidak mencapai 10 siswa. Selain sejumlah siswa tersebut, sebagian siswa yang lain cenderung ramai dan justru membahas permasalahan di luar topik matematika saat pelajaran berlangsung.

Salah satu alternatif untuk mengatasi permasalahan di atas adalah penggunaan strategi mengajar. Pemilihan strategi pembelajaran yang menarik dan dapat memicu siswa untuk ikut serta secara aktif dalam kegiatan belajar mengajar yaitu model pembelajaran aktif. Pada dasarnya pembelajaran aktif adalah suatu pembelajaran yang mengajak peserta didik untuk aktif turut serta dalam proses pembelajaran. Proses pembelajaran yang sesuai dengan kriteria tersebut adalah pembelajaran dengan pendekatan CTL dan pendekatan problem posing.

Pembelajaran kontekstual didasarkan pada hasil penelitian John Dewey tahun 1916 yang menyimpulkan bahwa siswa akan belajar dengan baik jika apa yang dipelajari terkait dengan apa yang telah diketahui dan terkait juga dengan kegiatan atau peristiwa yang terjadi di sekelilingnya (Hosnan \& Sikumbang, 2014, p. 267). Hal senada mengenai hal tersebut bahwa pembelajaran kontekstual didefinisikan sebagai cara untuk memperkenalkan konten dengan menggunakan berbagai teknik pembelajaran aktif yang dirancang untuk membantu siswa menghubungkan apa yang sudah mereka ketahui dengan apa yang mereka harapkan untuk dipelajari, dan untuk membangun pengetahuan baru dari analisis dan sintesis pada proses pembelajaran itu (Hudson \& Whisler, 2013, p. 54). Pendukung teori mengenai CTL yaitu hasil penelitian yang sudah dilakukan memberikan implikasi bahwa pendekatan pembelajaran kontekstual berpengaruh secara signifikan terhadap aspek kognitif dan afektif siswa dalam meningkatkan pemahaman konsep matematika siswa. Ditinjau dari aspek afektif siswa dalam pembelajaran matematika yang diajar melalui pendekatan pembelajaran kontekstual, siswa menunjukkan sikap positif terhadap proses pembelajaran matematika dan mata pelajaran matematika (Iffah, 2009).

Pembelajaran kontekstual merupakan sebuah proses pendidikan yang bertujuan untuk membantu siswa melihat makna dalam materi akademik yang mereka pelajari dengan cara menghubungkan mata pelajaran akademik dengan konteks kehidupan sehari-hari mereka, yaitu dengan konteks keadaan pribadi, sosial, dan budaya mereka (Johnson, 2002, p. 25). Selain itu, pengertian pembelajaran kontekstual merupakan pembelajaran yang menggabungkan contoh yang diambil dari pengalaman seharihari dalam kehidupan pribadi, sosial dan pekerjaan dan yang memberikan aplikasi dari materi yang dipelajari (Md Amin \& Md Kamaruddin, 2008, p. 283).

Pembelajaran matematika melalui pendekatan CTL dilaksanakan dengan mengacu pada tujuh komponennya, yaitu constructivism, inquiry, questioning, learning community, modelling, reflection, dan authentic assessment (Depdiknas, 2002, p.10). Semua komponen tersebut diturunkan menjadi indikator-indikator pembelajaran dan kemudian dituangkan dalam sintaks pembelajaran, yaitu: (1) Guru menggali pengetahuan awal siswa dengan melakukan tanya jawab yang berhubungan dengan materi. (constructivism, questioning); (2) Guru menyampaikan tujuan pembelajaran dan inti materi secara singkat. (constructivism, questioning); (3) Guru memberikan contoh-contoh nyata berkaitan dengan materi yang dipelajari. (modelling); (4) Guru membagi siswa ke dalam kelompokkelompok kecil. (learning community); (5) Guru menyajikan permasalahan kontekstual yang berkaitan dengan materi yang dipelajari. (terlampir pada LKS); (6) Siswa bekerja dalam kelompok untuk mendiskusikan permasalahan yang diberikan. (learning community, inquiry); (7) Perwakilan siswa dari beberapa kelompok mempresentasi-kan hasil diskusi di depan kelas. (modelling); (8) Guru dan siswa mengadakan refleksi terhadap kejadian, aktivitas, atau pengetahuan yang baru diterima. (reflection); (9) Guru memberikan tes kepada siswa sebagai penguatan. (authentic assessment); (10) Guru membimbing siswa mengambil kesimpulan. (reflection)

Pendekatan pembelajaran lain yang sesuai dengan tuntutan kebutuhan pendidikan adalah pendekatan problem posing. Problem posing dapat memberikan pemahaman yang lebih baik bagi siswa. Beberapa ahli sependapat bahwa problem posing memiliki peran besar kaitannya untuk mengoptimalkan prestasi belajar matematika. Problem posing diidentifikasi sebagai kegiatan penting dalam pendidikan matematika (Kojima \& Miwa, 2008, p. 1). Hal itu didukung oleh pernyataan bahwa problem posing adalah salah satu komponen kunci dari eksplorasi matematika (Cai \& Hwang, 2002, p. 403). 


\section{Jurnal Riset Pendidikan Matematika, 4 (1), 2017 - 71}

Nevi Narendrati

Dalam problem posing, siswa dirangsang untuk melakukan pengamatan, percobaan melalui berbagai data dan menganalisis hasilnya, dan menyusun masalah baru oleh mereka sendiri yang bisa diselesaikan dengan menggunakan pola yang sama ataupun berbeda (Singer, Ellerton, Cai, \& Leung, 2011, p. 139). Ketika menghadapi tugas problem posing, siswa membuatnya melalui analogi. Mereka mulai dari masalah yang diketahui dan mengubah satu atau lebih parameter, mendapatkan kembali rumusan model yang dibuat di awal (Singer, Pelczer, \& Voica, 2011, p. 1139).

Problem posing berkaitan dengan kedua hal, baik masalah baru maupun reformulasi dari masalah yang diberikan (Silver, 1994, p. 19). Dengan demikian, pembuatan soal atau masalah dapat dilakukan sebelum, selama, atau setelah penyelesaian masalah. Problem posing diklasifikasikan menjadi 3 tipe, yaitu free problem posing (problem posing bebas), semi-structured problem posing (problem posing semi-terstruktur), dan structured problem posing (problem posing terstruktur). Pemilihan tipe-tipe itu dapat didasarkan pada materi matematika, kemampuan siswa, hasil belajar siswa, atau tingkat berpikir siswa (El Sayed, 2002, pp. 59-60). Menurut tipe problem posing bebas, siswa diminta untuk membuat soal secara bebas berdasarkan situasi kehidupan sehari-hari. Pada problem posing semi-terstruktur, siswa diberikan suatu situasi bebas atau terbuka dan diminta untuk mengeksplorasinya dengan menggunakan pengetahuan, keterampilan, atau konsep yang telah mereka miliki. Bentuk soal yang dapat diberikan antara lain membuat soal berdasarkan soal yang diberikan, membuat soal dengan konteks yang sama dengan soal yang diberikan, dst. Dalam tipe problem posing terstruktur, siswa diminta untuk membuat soal berdasarkan soal yang diketahui dengan mengubah data atau informasi yang diketahui.

Langkah-langkah atau sintaks penerapan pendekatan pembelajaran problem posing adalah: (1) Guru menggali pengetahuan awal siswa dengan melakukan tanya jawab yang berhubungan dengan materi; (2) Guru menyampaikan tujuan pembelajaran; (3) Guru memberikan penjelasan singkat tentang materi yang akan dipelajari; (4) Guru memberikan situasi masalah. (terlampir pada LKS); (5) Siswa mengajukan soal dari situasi yang diberikan (posing problems). Soal yang diajukan dapat berupa problem posing semi-terstruktur maupun problem posing terstruktur, tergantung pada petunjuk yang ada dalam LKS. Bentuk soal yang dapat dibuat pada problem posing semiterstruktur adalah soal yang sama dengan konteks yang diberikan. Pada problem posing terstruktur, siswa diminta untuk membuat soal berdasarkan soal yang diketahui dengan mengubah data atau informasi yang sudah ada; (6) Siswa memberikan jawaban atau penyelesaian soal dari pertanyaan yang telah diajukan oleh siswa; (7) Secara acak guru meminta siswa untuk mempresentasikan soal dan jawaban yang telah dibuat; (8) Guru membimbing siswa mengambil kesimpulan.

Berdasarkan masalah prestasi dan minat belajar matematikan di SMK ditambahkan dengan definisi beretas fakta CTL dan problem posing berpotensi untuk memecahkan kedua masalah tersebut maka penelitian ini bertujuan untuk mendeskripsikan keefektifan pembelajaran statistika melalui pendekatan CTL dan pendekatan problem posing ditinjau dari prestasi belajar dan minat belajar matematika; dan menyelidiki manakah yang lebih efektif antara pembelajaran statistika melalui pendekatan CTL dan pendekatan problem posing ditinjau dari prestasi belajar dan minat belajar matematika siswa SMK.

\section{METODE}

Subjek pada penelitian ini adalah siswa kelas XI Animasi A dan XI Animasi B SMK Negeri 5 Yogyakarta Tahun Ajaran 2014/2015 yang masing-masing terdiri atas 30 siswa. Penelitian ini merupakan eksperimen semu dengan desain pretest-posttest non-equivalent group design. Pada desain ini terdapat dua kelas eksperimen. Kelas eksperimen pertama yang menerapkan pembelajaran dengan pendekatan CTL, dan kelas eksperimen kedua yang menerapkan pembelajaran dengan pendekatan problem posing. Adapun proses pengumpulan data yang digunakan dalam penelitian ini adalah mengumpulkan data sebelum diberikan perlakuan yaitu dengan memberikan pretest prestasi belajar dan angket minat belajar. Selanjutnya melakukan penelitian dengan memberikan perlakuan dengan menerapkan pendekatan CTL pada kelas eksperimen pertama, dan pendekatan problem posing pada kelas eksperimen kedua, serta mengumpulkan data setelah diberikan perlakuan pada masing-masing kelas eksperimen, yaitu dengan memberikan posttest prestasi belajar dan angket minat belajar matematika. Berdasarkan hasil uji coba instrumen tes prestasi dan angket minat belajar matematika diperoleh 
koefisien reliabilitas berturut-turut sebesar 0,597 dan 0,838 . Oleh karena itu, berdasarkan nilai koefisien reliabilitas dapat diketahui nilai Standard Error of Measurement (SEM) untuk tes prestasi dan angket minat belajar matematika berturut-turut adalah sebesar 1,135 dan 3,535.

Semakin kecil nilai SEM, maka instrumen akan semakin dapat dipercaya. Karena itu interpretasi terhadap koefisien reliabilitas dapat dilakukan dengan memeriksa kecermatan hasil ukur yang ditunjukkan oleh besarnya SEM dan menggunakannya untuk estimasi interval skor sebenarnya. Setelah nilai SEM diperoleh, langkah selanjutnya adalah menghitung interval kepercayaan. Dengan menggunakan 68\% tingkat kepercayaan, dapat diketahui interval kepercayaan skor sebenarnya melalui perhitungan menggunakan rumus sebagai berikut.

$x-S E M \leq T \leq x+S E M$

Keterangan :

$x$ : skor perolehan siswa

$z_{c}$ : nilai kritis dari deviasi standar normal (1)

Semakin kecil nilai galat baku pengukuran (nilai SEM) maka akan semakin sempit interval kepercayaan skor sebenarnya yang berarti bahwa hasil tes semakin cermat. Namun sebaliknya, semakin besar nilai galat baku pengukuran (nilai SEM) maka akan semakin lebar interval kepercayaan yang terjadi. Itu artinya hasil pengukuran semakin kurang cermat.

Teknik analisis data yang digunakan dalam penelitian ini adalah analisis deskriptif dan inferensial. Analisis deskriptif untuk mendeskripsikan keadaan sebelum dan setelah diberikan perlakuan pada kedua kelas ditinjau dari masing-masing variabel terikatnya. Analisis inferensial dilakukan untuk mengambil kesimpulan berdasarkan data yang telah diperoleh selama proses penelitian berlangsung. Analisis inferensial ini terdiri atas uji keefektifan dan uji perbandingan keefektifan pembelajaran matematika.

Sebelum dilakukan analisis keefektifan perlu diketahui bahwa keefektifan pembelajaran matematika dapat ditentukan berdasarkan kriteria pencapaian tujuan pembelajaran yang ditunjukkan dengan ketuntasan belajar siswa dalam pembelajaran matematika. Pendekatan pembelajaran dikatakan efektif ditinjau dari prestasi belajar apabila diperoleh rata-rata mencapai nilai KKM, yaitu 75. Sementara itu, suatu pendekatan pembelajaran dikatakan efektif ditinjau dari minat belajar matematika apabila lebih dari $75 \%$ siswa memperoleh skor minat belajar dengan kategori sedang, tinggi, dan sangat tinggi.

Data-data yang diperoleh selama penelitian berlangsung harus memenuhi uji asumsi terlebih dahulu sebelum dilakukan proses analisis. Uji asumsi yang harus dipenuhi adalah uji normalitas dengan menggunakan uji Kolmogorov Smirnov. Selain itu, homogenitas kedua kelompok diuji dengan menggunakan uji Box-M. Kriteria keputusan untuk normalitas dan homogenitas yaitu jika nilai signifikansi yang diperoleh lebih dari 0,05; maka data berasal dari populasi yang berdistribusi normal dan matriks kovarians kedua populasi tersebut homogen.

Setelah melewati proses uji asumsi, maka dilanjutkan dengan menganalisis keefektifan dari pendekatan CTL dan pendekatan problem posing, yaitu dengan one sample t-test ditinjau dari aspek prestasi belajar dan uji proporsi ditinjau dari aspek minat belajar matematika. Sementara itu, analisis perbedaan keefektifan antara pembelajaran statistika melalui pendekatan CTL dan pendekatan problem posing dilakukan dengan uji Multivariate Analysis of Variance (MANOVA) $T^{2}$ Hotelling (Stevens, 2009, p. 148). Taraf signifikansi yang digunakan pada uji keefektifan maupun uji komparasi adalah 0,05 . Selanjutnya jika terdapat perbedaan antara kedua pendekatan tersebut, maka dilakukan uji lanjut yaitu uji univariat untuk melihat variabel tertentu yang berkontribusi terhadap perbedaan secara keseluruhan. Apabila hasilnya tidak menunjukkan adanya perbedaan, maka pengujian tidak dilanjutkan.

\section{HASIL DAN PEMBAHASAN}

\section{Hasil}

Data yang dianalisis adalah data posttest setelah siswa diberi perlakuan pembelajaran berupa penerapan pendekatan CTL dan pendekatan problem posing. Hasil penelitian ini terdiri atas hasil uji keefektifan pendekatan pembelajaran dan uji perbandingan keefektifan pembelajaran melalui pendekatan CTL dan pendekatan problem posing. Hasil uji keefektifan dengan menggunakan one sample t-test dan uji proporsi untuk kedua variabel terikat disajikan pada Tabel 2 dan Tabel 3.

Tabel 2. Hasil Uji One Sample T-Test Aspek Prestasi Kelas CTL

\begin{tabular}{|c|c|c|c|c|}
\hline Aspek & Pendekatan & $\mathbf{t}$ & df & Sig. \\
\hline Prestasi & CTL & 2,721 & 27 & 0,011 \\
\hline
\end{tabular}

Tabel 2, nilai signifikansi untuk kelas CTL pada 
aspek prestasi belajar adalah $0,011<0,05$. Hal ini berarti bahwa pendekatan CTL efektif ditinjau dari prestasi belajar.

Tebel 3. Hasil Uji Proporsi Aspek Minat Belajar Kelas CTL

\begin{tabular}{ccc}
\hline Pendekatan & $\boldsymbol{z}_{\text {hitung }}$ & $\boldsymbol{z}_{\text {tabel }}$ \\
\hline CTL & 0,2261 & 0,7734 \\
\hline
\end{tabular}

Berdasarkan hasil perhitungan pada Tabel

3 , diperoleh $z_{\text {hitung }}<z_{\text {tabel }}$, sehingga $\mathrm{H}_{0}$ diterima.

Kesimpulan dari uji proporsi tersebut adalah pembelajaran melalui pendekatan CTL tidak efektif ditinjau dari aspek minat belajar matematika siswa. Selanjutnya, Tabel 4 dan Tabel 5 berikut menyajikan hasil uji keefektifan pendekatan problem posing pada kedua variabel terikat.

Tabel 4. Hasil Uji One Sample T-Test Aspek Prestasi Kelas PP

\begin{tabular}{ccccc}
\hline Aspek & Pendekatan & t & df & Sig. \\
\hline Prestasi & PP & 4,280 & 26 & 0,000 \\
\hline
\end{tabular}

Berdasarkan hasil one sample t-test opada

Tabel 4, nilai signifikansi untuk kelas PP pada aspek prestasi belajar adalah 0,000 . Hal ini berarti bahwa pendekatan problem posing efektif ditinjau dari prestasi belajar.

Tabel 5. Hasil Uji Proporsi Aspek Minat Belajar Kelas PP

\begin{tabular}{ccc}
\hline Pendekatan & $\boldsymbol{z}_{\text {hitung }}$ & $\boldsymbol{z}_{\text {tabel }}$ \\
\hline PP & 2,1121 & 0,7734
\end{tabular}

Berdasarkan hasil perhitungan pada Tabel 5 , diperoleh $z_{\text {hitung }}>z_{\text {tabel }}$, sehingga $\mathrm{H}_{0}$ ditolak. Kesimpulan dari uji proporsi tersebut adalah pembelajaran melalui pendekatan problem posing efektif ditinjau dari aspek minat belajar matematika siswa.

Setelah melakukan uji keefektifan, dilanjutkan dengan menguji perbedaan keefektifan antara pembelajaran melalui pendekatan CTL dan pendekatan problem posing menggunakan uji multivariat $T^{2}$ Hotelling dengan bantuan software SPSS 21 for windows. Hasil perhitungan tersebut menunjukkan bahwa taraf signifikansi yang diperoleh sebesar 0,169>0,05. Dengan demikian, $\mathrm{H}_{0}$ diterima dan dapat disimpulkan tidak terdapat perbedaan keefektifan secara signifikan antara kelas eksperimen satu (kelas CTL) dan kelas eksperimen dua (kelas PP) ditinjau dari prestasi belajar dan minat belajar matematika siswa. Karena hasil perhitungan tersebut menyatakan bahwa tidak terdapat perbedaan keefektifan, maka analisis tidak dilanjutkan.

\section{Pembahasan}

Sesuai dengan harapan dari peraturan pemerintah terkait tentang pendidikan, inovasi dalam bidang pembelajaran termasuk pembelajaran matematika di sekolah menengah memang sangat dibutuhkan. Inovasi dalam proses belajar mengajar salah satunya adalah inovasi yang bisa dilakukan oleh guru dalam menerapkan suatu pendekatan pembelajaran. Namun permasalahannya, suatu pendekatan pembelajaran yang ada belum tentu efektif untuk diterapkan pada setiap pokok bahasan atau materi matematika. Oleh karena itu, perlu dilakukan suatu penelitian.

Dalam penelitian ini, diterapkan pendekatan CTL dan pendekatan problem posing pada pembelajaran statistika siswa kelas XI SMK Negeri 5 Yogyakarta. Beberapa hal yang diteliti dalam penelitian ini antara lain keefektifan pendekatan CTL dan pendekatan problem posing ditinjau dari dua variabel terikat dan kemudian menentukan ada tidaknya perbedaan keefektifan diantara kedua kelas eksperimen ditinjau dari aspek prestasi belajar dan minat belajar matematika siswa.

Prestasi belajar matematika dan minat siswa kelas XI SMK Negeri 5 Yogyakarta terhadap matematika sebelum diadakan pembelajaran dengan menggunakan pendekatan CTL dan problem posing belum maksimal. Metode ekspositori yang selalu diterapkan guru membuat guru mendominasi kegiatan belajar mengajar. Akibatnya, siswa menjadi cepat bosan dalam belajar matematika. Hal tersebut berdampak pada minat belajar siswa yang kurang dan pada akhirnya prestasi belajar siswa juga sangat perlu untuk ditingkatkan.

Beberapa dasar pemikiran untuk melakukan kegiatan penelitian dengan menerapkan suatu pendekatan pembelajaran yang berbeda dari yang sudah biasa diterapkan di SMK Negeri 5 Yogyakarta adalah karena persentase penguasaan materi statistika mengalami penurunan untuk tiga kemampuan yang diujikan pada Ujian Nasional dan aspek minat belajar yang berkorelasi positif dengan prestasi belum banyak mendapat perhatian guru di sekolah. Pendekatan pembelajaran yang akan digunakan belum pernah diterapkan pada materi statistika, maka hal pertama yang harus dikaji adalah keefektifannya.

Untuk mengetahui tingkat keefektifan pendekatan CTL dan pendekatan problemposing ditinjau dari aspek prestasi belajar digu- 


\section{Jurnal Riset Pendidikan Matematika, 4 (1), 2017 - 74}

Nevi Narendrati

nakan acuan kriteria ketuntasan minimal (KKM) yang ditetapkan oleh sekolah yakni 75 . Pendekatan pembelajaran yang ditinjau dari aspek prestasi belajar dikatakan efektif jika ratarata nilai siswa mencapai 75. Sedangkan untuk mengetahui tingkat keefektifan pendekatan CTL dan pendekatan problem posing ditinjau dari aspek minat belajar matematika siswa didasarkan pada tabel kriteria minat belajar matematika. Pembelajaran ditinjau dari aspek minat belajar matematika dikatakan efektif jika lebih dari $75 \%$ siswa mencapai skor lebih dari atau sama dengan 54 atau minimal termasuk dalam kategori sedang.

Siswa kelas XI Animasi A SMK Negeri 5 Yogyakarta dalam penelitian ini sebagai kelas eksperimen 1 dengan menerapkan pendekatan CTL. Berdasarkan hasil penelitian, ternyata pembelajaran matematika dengan pendekatan CTL efektif ditinjau dari prestasi belajar tetapi belum efektif jika ditinjau dari minat belajar matematika siswa. Penyebab ketidakefektifan pendekatan CTL ditinjau dari minat belajar diduga berkaitan dengan teori yang diungkapkan oleh Alderman (2008, pp. 240-241), bahwa minat personal siswa berkembang secara perlahan dari waktu ke waktu. Selain itu dalam teori tersebut juga dijelaskan, minat situasional yang diperoleh dari beberapa kegiatan pembelajaran atau materi teks yang digunakan di kelas memiliki dua kemungkinan hasil, yaitu dapat atau tidak dapat memberikan efek jangka panjang pada siswa.

Keefektifan pembelajaran melalui pendekatan CTL sesuai dengan hasil penelitian Setiawan \& Harta (2014, p. 252), bahwa di dalam kelas kontekstual para siswa belajar untuk menemukan makna dalam pelajaran mereka dengan cara menghubungkan materi akademik dengan konteks kehidupan keseharian mereka. Keterkaitan yang mengarah pada makna ini adalah bagian terpenting dalam pembelajaran kontekstual, karena dengan makna akan memberi alasan mereka untuk belajar sehingga kesungguhan untuk belajar semakin baik. Selain itu, hasil yang telah diperoleh juga didukung oleh pernyataan yang menjelaskan bahwa pembelajaran dengan pendekatan CTL memberikan peluang pada siswa untuk lebih berperan aktif dalam belajar (Rahmawati ES \& Harta, 2014, p. 123). Hasil penelitian lain mengenai pengembangan perangkat pembelajaran matematika untuk siswa SMK dengan pendekatan kontekstual juga memberikan hasil yang efektif ditinjau dari prestasi belajar matematika siswa karena persentase siswa tuntas atau hasil tesnya telah mencapai KKM sudah lebih dari $75 \%$, yaitu sebanyak 87,5\% (Suhartini \& Santoso, 2014, p. 75).

Dalam pembelajaran statistika yang telah diterapkan melalui pendekatan CTL, siswa dikondisikan belajar dalam kelompok-kelompok kecil terdiri atas 3 sampai 4 orang. Pembagian kelompok dilakukan secara heterogen baik dari jenis kelamin, agama, dan kemampuan awal siswa. Data kemampuan awal siswa merupakan data pretest. Proses pembelajaran diawali dengan menghubungkan antara materi dan konteks kehidupan nyata, siswa diberikan beberapa contoh, dan diakhiri dengan kuis sebagai penguatan pemahaman siswa. Hal ini sesuai dengan teori bahwa CTL bertujuan untuk membantu siswa melihat makna dalam materi akademik yang mereka pelajari dengan menghubungkan mata pelajaran akademik dengan konteks kehidupan sehari-hari mereka, yaitu dengan konteks keadaan pribadi, sosial, dan budaya mereka. Selama proses pembelajaran di kelas CTL, siswa dapat berpartisipasi aktif melalui kegiatan diskusi kelompok. Siswa akan bertanya kepada teman sekelompoknya ataupun guru jika mereka belum memahami materi dan permasalahan dalam LKS.

Pada kelas yang berbeda, yaitu kelas XI Animasi B SMK Negeri 5 Yogyakarta dalam penelitian ini sebagai kelas eksperimen 2 belajar statistika melalui pendekatan problem posing. Berdasarkan hasil penelitian, pembelajaran matematika dengan pendekatan problem posing efektif ditinjau dari prestasi belajar dan minat belajar matematika. Penelitian ini didukung oleh hasil penelitian Ghasempour, Bakar, \& Jahanshahloo (2013) yang menunjukkan adanya berbagai keunggulan pendekatan problem posing. Salah satu keunggulan yang disimpulkan dari hasil penelitian mereka adalah bahwa problem posing dapat merangsang kemampuan berpikir tingkat tinggi siswa. Dengan demikian, pemahaman mereka menjadi lebih baik terhadap materi yang sedang dipelajari yaitu statistika.

Dalam pembelajaran dengan pendekatan problem posing, siswa bebas membuat pertanyaan sekaligus jawaban sendiri ataupun secara berkelompok. Pada penelitian ini pembelajaran di kelas problem posing dilakukan sebanyak 6 kali. Selama pertemuan tersebut, siswa dikondisikan untuk belajar dalam kelompok pada pertemuan pertama dan kedua. Hal ini dimaksudkan agar siswa lebih mudah beradaptasi dan memahami sintaks pendekatan pembelajaran 
problem posing yang diterapkan, terutama dalam hal pembuatan soal.

Pada pertemuan ketiga dan seterusnya di kelas problem posing, masing-masing siswa dikondisikan untuk belajar dengan bantuan LKS dan membuat soal secara individu. Soal yang dibuat oleh siswa juga diselesaikan oleh mereka sendiri. Dalam praktiknya, situasi ini lebih efisien karena peneliti mempertimbangkan kecepatan setiap siswa dalam memahami materi sekaligus menyelesaikan kegiatan pada LKS. Sehingga dengan alokasi waktu yang ada masih belum memungkinkan untuk menukar soal antara siswa satu dengan lainnya. Tetapi dengan keadaan itu siswa sudah cukup terlatih untuk berpikir mengenai situasi atau permasalahan yang diberikan guru. Hanya saja, pertanyaan yang dibuat oleh siswa kebanyakan masih bersifat monoton. Artinya, keberagaman pertanyaan jarang ditemukan. Kemajuan yang berarti terjadi pada dua pertemuan terakhir, dimana sebagian siswa sudah lebih berinisiatif untuk mengubah situasi soal dari apa yang telah dicontohkan dalam LKS.

Secara teoretis, minat belajar berbanding lurus dengan prestasi belajar yang diraih. Artinya, apabila minat belajar siswa tinggi maka prestasi belajarnya juga akan bagus, dan sebaliknya. Berdasarkan hasil pengumpulan data, diperoleh rata-rata skor minat belajar matematika siswa pada kelas eksperimen 1 sebesar 59,81 dan kelas eksperimen 2 sebesar 60,07. Keduanya termasuk ke dalam kategori sedang. Hasil penelitian tersebut menunjukkan bahwa minat belajar siswa tidak berbeda secara signifikan antara kelas yang menerapkan pendekatan CTL dan problem posing.

Selanjutnya, meninjau kembali keadaan minat awal siswa, tidak terdapat peningkatan yang berarti di kedua kelas eksperimen setelah dilakukan pembelajaran. Pada kelas eksperimen 1 (CTL), rata-rata skor minat awal siswa sebesar 56,96 (kategori sedang) dan rata-rata skor minat setelah perlakuan sebesar 59,81 (kategori sedang). Pada kelas eksperimen 2, rata-rata skor minat awal siswa sebesar 58,61 (kategori sedang) dan rata-rata skor minat setelah perlakuan sebesar 60,07 (kategori sedang). Secara keseluruhan minat belajar siswa berada dalam kategori sedang. Ini bukan berarti pendekatan pembelajaran yang diterapkan tidak membantu siswa untuk meningkatkan minat belajarnya. Tetapi seperti dipahami bahwa upaya meningkatkan aspek afektif, dalam hal ini adalah minat belajar matematika, bukanlah sesuatu yang mudah, sederhana, dan mungkin akan membutuhkan waktu yang tidak sebentar. Hasil penelitian menunjukkan bahwa minat belajar meningkat pada beberapa siswa. Peningkatan persentase minat belajar matematika siswa dapat dilihat pada Tabel 6.

Tabel 6. Peningkatan Persentase Minat Belajar Matematika Siswa pada Kelas CTL dan PP

\begin{tabular}{ccc}
\hline \multirow{2}{*}{ Kriteria } & \multicolumn{2}{c}{ Peningkatan } \\
\cline { 2 - 3 } & CTL & PP \\
\hline Sangat tinggi & 0 & 0 \\
Tinggi & 15,38 & 11,64 \\
Sedang & 3,84 & 5,96 \\
Rendah & 11,54 & 17,59 \\
Sangat rendah & 3,85 & 0 \\
\hline Dari dua pendekatan yang & diterapkan
\end{tabular}
pada kedua kelas eksperimen, diperoleh hasil bahwa masing-masing efektif ditinjau dari prestasi belajar dan minat belajar matematika, kecuali pendekatan CTL pada aspek minat belajar. Berdasarkan hasil uji multivariat dengan SPSS 21 for windows, nilai Sig. $<0,05$ sehingga dapat disimpulkan bahwa pendekatan pembelajaran yang diterapkan efektif pada kedua kelas eksperimen.

Dari uraian tersebut, diketahui bahwa pendekatan CTL dan pendekatan problem posing masing-masing efektif ditinjau dari aspek prestasi belajar matematika siswa. Selain itu, diketahui pula kondisi awal dari kedua kelompok eksperimen tersebut adalah sama atau homogen. Berdasarkan pada dua hal ini, maka perlu diketahui pendekatan mana yang lebih efektif diantara pendekatan CTL dan pendekatan problem posing. Untuk dapat mengetahui pendekatan mana yang lebih efektif ditinjau dari prestasi belajar dan minat belajar matematika siswa, maka dilakukan komparasi.

Berdasarkan hasil analisis multivariat dengan MANOVA, diperoleh hasil bahwa hipotesis nol diterima. Ini artinya tidak terdapat perbedaan keefektifan antara pembelajaran melalui pendekatan CTL dan pembelajaran melalui pendekatan problem posing ditinjau dari prestasi belajar dan minat belajar matematika siswa. Karena tidak terdapat perbedaan keefektifan di antara kedua pendekatan pembelajaran tersebut, maka tidak dapat dilakukan uji lanjut $t$-univariat guna menentukan variabel tertentu yang berkontribusi terhadap perbedaan secara keseluruhan.

Tidak adanya perbedaan antara kedua pendekatan pembelajaran yang diterapkan disebabkan pembelajaran matematika pada kedua 
kelas eksperimen dilaksanakan oleh guru yang sama, sehingga guru melakukan perbaikan pembelajaran berdasarkan pembelajaran yang telah dilaksanakan pada kelompok sebelumnya. Selain itu, pada saat pembelajaran pada kedua kelas ternyata ditemukan kesamaan pada beberapa sintaks dari kedua pendekatan tersebut, diantaranya adalah pemberian materi singkat serta beberapa contoh di awal pelajaran dan adanya presentasi setelah kegiatan inti pembelajaran dilaksanakan. Dengan adanya presentasi ini membuat kesiapan siswa lebih baik dalam belajar dan memahami materi yang dipelajari.

Hasil dari penerapan kedua pendekatan tersebut memang tidak ada perbedaan keefektifan ditinjau dari prestasi belajar dan minat belajar matematika siswa. Akan tetapi, dapat dilihat rata-rata dan persentase siswa yang memperoleh skor minimal baik untuk prestasi belajar maupun minat belajar matematika. Berdasarkan hasil uji hipotesis, diperoleh rata-rata prestasi belajar pada pendekatan problem posing 81,67 dengan standar deviasi 7,10. Sementara itu, untuk ratarata skor minat belajar yang diperoleh adalah 60,07 dengan standar deviasi 7,37. Hal ini menunjukkan problem posing memberikan peningkatan hasil yang lebih tinggi jika dibandingkan dengan pendekatan CTL.

\section{SIMPULAN}

Berdasarkan hasil penelitian dan pembahasan tersebut, maka dapat disimpulkan bahwa: (1) pembelajaran statistika melalui pendekatan CTL efektif ditinjau dari prestasi belajar tetapi tidak efektif ditinjau dari minat belajar matematika siswa SMK; (2) pembelajaran statistika melalui pendekatan problem posing efektif ditinjau dari prestasi belajar dan minat belajar matematika siswa SMK; dan (3) tidak terdapat perbedaan keefektifan secara signifikan pada penerapan pembelajaran statistika melalui pendekatan CTL dan pendekatan problem posing ditinjau dari prestasi belajar dan minat belajar matematika siswa SMK.

\section{DAFTAR PUSTAKA}

Alderman, M. K. (2008). Motivation for achievement: Possibilities for teaching and learning. Mahwah, NJ: Routledge.

Beall, S. (2010). A case study of teaching to multiple intelligences-music and mathematics. Diakses tanggal 29 Juni 2014 dari http://scottbeall.com/MI\%20 Case\%20study.htm
Cai, J., \& Hwang, S. (2002). Generalized and generative thinking in US and Chinese students' mathematical problem solving and problem posing. The Journal of Mathematical Behavior, 21(4), 401-421. http://doi.org/10.1016/S07323123(02)00142-6

Depdiknas. (2002). Pendekatan kontekstual (contextual teaching and learning (CTL)). Jakarta: Depdiknas.

Depdiknas. (2012). Laporan Hasil dan Statistik Nilai Ujian Nasional Tahun Pelajaran 2011/2012. Jakarta: Badan Standar Nasional Pendidikan.

Depdiknas. (2013). Laporan Hasil dan Statistik Nilai Ujian Nasional Tahun Pelajaran 2012/2013. Jakarta: Badan Standar Nasional Pendidikan.

El Sayed, R. A.-E. (2002). Effectiveness of problem posing strategies on prospective mathematics teachers' problem solving performance. Journal of Science and Mathematics Education in S.E. Asia, $X X V(1), \quad 56-69$. Retrieved from http://www.recsam.edu.my/R\&D_Journal s/YEAR2002/2002Vol25No1/56-69.pdf

Gable, R. K. (1986). Instrument development in the affective domain. Dordrecht: Springer Netherlands. http://doi.org/10.1007/97894-015-7259-0

Ghasempour, Z., Bakar, M. N., \& Jahanshahloo, G. R. (2013). Innovation in teaching and learning through problem posing tasks and metacognitive strategies. International Journal of Pedagogical Innovatio, 1(1), 57-66. Retrieved from http://www.naturalspublishing.com/files/p ublished/2wh2o22kcq662p.pdf

Hosnan, M., \& Sikumbang, R. (2014). Pendekatan saintifik dan kontekstual dalam pembelajaran abad 21: Kunci sukses implementasi kurikulum 2013. Bogor: Ghalia Indonesia.

Hudson, C. C., \& Whisler, V. R. (2013). Contextual teaching and learning for practitioners. Systemics, Cybernetics and Informatics, 6(4), 54-58. Retrieved from http://www.iiisci.org/journal/cv\$/sci/pdfs/ e668ps.pdf

Iffah, S. (2009). Keefektifan pendekatan pembelajaran kontekstual dalam meningkatkan pemahaman konsep matematika siswa SMP Negeri 2 Depok 
Sleman Yogyakarta. Tesis, tidak dipublikasikan. Universitas Negeri Yogyakarta.

Johnson, E. B. (2002). Contextual teaching and learning: what it is and why it's here to stay. Thousand Oaks, California: Corwin Press.

Kojima, K., \& Miwa, K. (2008). A system that facilitates diverse thinking in problem posing. International Journal of Artificial Intelligence in Education, 18(3), 209236. Retrieved from http://dl.acm.org/citation.cfm?id=145428 1

Md Amin, Z., \& Md Kamaruddin, N. K. (2008). A study of the effectiveness of the contextual lab activity in the teaching and learning engineering statistics at the Universiti Tun Hussein Onn Malaysia (UTHM). In Proceedings of the 13th Asian Technology Conference in Mathematics (pp. 281-548). Bangkok: Suan Sunandha Rajabhat University. Retrieved from http://eprints.uthm.edu.my/112/1/zulkarna in\%2Chafisah.pdf

Menteri Pendidikan Nasional. Peraturan Menteri Pendidikan Nasional RI nomor 22, tahun 2006, tentang standar isi intuk satuan pendidikan dan menengah, Peraturan Menteri Pendidikan Nasional (2006).

Muijs, D., \& Reynolds, D. (2005). Effective teaching: Evidence and practice. London: SAGE Publications.

Presiden Republik Indonesia. (2013). Peraturan Pemerintah Nomor 65, Tahun 2013, tentang Standar Proses.

Presiden Republik Indonesia. Undang-Undang Republik Indonesia nomor 20 tahun 2003 tentang sistem pendidikan nasional, Pub. L. No. 20 (2003). Retrieved from http://sindikker.dikti.go.id/dok/UU/UU20 -2003-Sisdiknas.pdf

Rahmawati ES, Y., \& Harta, I. (2014). Keefektifan pendekatan open-ended dan
CTL ditinjau dari hasil belajar kognitif dan afektif. Jurnal Riset Pendidikan Matematika, $\quad 1(1), \quad 113$. http://doi.org/10.21831/jrpm.v1i1.2669

Setiawan, R. H., \& Harta, I. (2014). Pengaruh pendekatan open-ended dan pendekatan kontekstual terhadap kemampuan pemecahan masalah dan sikap siswa terhadap matematika. Jurnal Riset Pendidikan Matematika, 1(2), 241. http://doi.org/10.21831/jrpm.v1i2.2679

Silver, E. A. (1994). On mathematical problem posing. For the Learning of Mathematics, 14(1), 19-28. Retrieved from https://www.jstor.org/stable/40248099?se $\mathrm{q}=1$ \#page_scan_tab_contents

Singer, F. M., Ellerton, N., Cai, J., \& Leung, E. C. K. (2011). Problem posing in mathematics learning and teaching: A research agenda. In Proceedings of the 35 th Conference of the International Group for the Psychology of Mathematics Education (pp. 137-166). Ankara.

Singer, F. M., Pelczer, I., \& Voica, C. (2011). Problem posing and modification as a criterion of mathematical creativity. In Marta Pytlak, Tim Rowland, \& Ewa Swoboda (Eds.), Proceedings of the Seventh Congress of the European Society for Research in Mathematics Education (pp. 1133-1142). Rzeszów, Poland: University of Rzeszów.

Stevens, J. P. (2009). Applied multivariate statistics for the social sciences. New York: Routledge.

Suhartini, S., \& Santoso, R. H. (2014). Pengembangan perangkat pembelajaran matematika untuk siswa SMK jurusan akuntansi di Sleman dengan pendekatan pembelajaran kontekstual. Jurnal Riset Pendidikan Matematika, 1(1), 69. http://doi.org/10.21831/jrpm.v1i1.2665

Woolfolk, A. (2007). Educational psychology. New York: Pearson Education, Inc. 